\title{
Oroclines of the southern New England Orogen, eastern Australia
}

\author{
School of Earth Sciences, The University of Queensland, St Lucia, QLD 4072, Australia. E-mail: g.rosenbaum@uq.edu.au
}

A series of tight bends (oroclines) are recognised in the late Paleozoic-early Mesozoic southern New England Orogen between Brisbane and Newcastle, but their exact geometry and tectonic evolution are still debated. This contribution provides an outline of the different tectonic elements within the orogen and the relationships of these elements with the oroclinal structure. Pre-oroclinal tectonic elements were derived from a Devonian-Carboniferous subduction zone, and include forearc basin terranes and accretionary wedge rocks that are separated from each other by a narrow belt of serpentinites and high-pressure rocks. Rocks are predominantly steeply dipping and their map-view pattern delineates three bends: the Z-shaped Texas and Coffs Harbour oroclines in the north and the U-shaped Manning Orocline in the south. During the early Permian (298-288 Ma), the area was affected by widespread, mostly S-type, magmatism that heralded a period of crustal extension accompanied by the formation of sedimentary rift basins. The spatial distribution of early Permian granitoids mimics the shape of the oroclines, which further defines a fourth bend, the Nambucca Orocline. Whether these curvatures formed by bending of a quasi-linear belt, or as primary early Permian arcuate features, is an unresolved question that warrants further paleomagnetic, geochronological and structural investigations.

\section{Introduction}

The Devonian-Early Triassic New England Orogen (NEO) in eastern Australia is the youngest orogenic component in the Australian continent. The northern part of the orogen, from northern Queensland to Brisbane (Figure 1a) is oriented NW-SE parallel to the continental margin. In contrast, the southern NEO, in the area between Brisbane and Newcastle (Figure 1a, b), is characterised by a series of sharp bends, herein referred to as the New England Oroclines.

This paper focuses on the structure and tectonics of the New England Oroclines. The exact geometry of these oroclines is controversial, and there are different interpretations to the structural grain of the orogen. The simplest structural model is of a Z-shaped double orocline, comprising the so-called Texas and Coffs Harbour oroclines (Murray et al., 1987; Offler and Foster, 2008) (Figure 1c). Evidence supporting the existence of these oroclines is the curved orientations of structural fabrics (Korsch, 1981; Lennox and Flood, 1997; Aubourg et al., 2004; Li et al., 2012) and the curvature of aeromagnetic lineaments (Figure 1c).

A different model, proposed by a number of authors (Cawood and Leitch, 1985; Korsch and Harrington, 1987; Glen, 2005; Cawood et al., 2011b), considers an additional orocline farther S, the Manning Orocline (Figure 1d). This orocline has been suggested based on (1) paleomagnetic data showing block rotations of forearc basin terranes around vertical axes (Geeve et al., 2002; Klootwijk, 2009; Cawood et al., 2011b); (2) the recognition of a contorted serpentinite belt (Korsch and Harrington, 1987); and (3) the curved structure delineated by Early Permian (298-288 Ma) granitoids (Rosenbaum, 2010; Rosenbaum et al., 2012). Nevertheless, structural information supporting the existence of this orocline is more ambiguous.

Based on the lateral continuation of early Permian granitoids, an even more complex structural model that involves four bends, has been proposed (Rosenbaum, 2010; Rosenbaum et al., 2012) (Figure 1e). The suggested fourth bend has been named the Nambucca Orocline (Rosenbaum, 2010).

The kinematics associated with the development of the New England oroclines is relatively poorly constrained, with only patchy structural, paleomagnetic and geochronological data. In this respect, 'orocline' is used here in a general sense, as referring to orogenic curvatures rather than the strict sense that implies a secondary bending of an originally linear belt (Weil and Sussman, 2004). This paper aims to highlight the structure of the oroclines by outlining the spatiotemporal distribution of different tectonic elements within the southern NEO. This will be followed by a discussion on the large-scale tectonic implications of this spectacularly contorted orogenic structure.

\section{Tectonic elements}

\section{Devonian-Carboniferous subduction complex}

The greater part of the exposed southern NEO is a DevonianCarboniferous convergent margin complex (Figure 2) comprising forearc basin rocks of the Tamworth Belt and correlative terranes, and accretionary metasedimentary rocks of the Tablelands Complex. These domains are separated from each other by a tectonic contact, the Peel-Manning Fault System (PFZ and MFZ in Figure 1b), along which a lithological assemblage of serpentinites, blueschists and eclogites, is exposed. This assemblage, hereinafter referred to as the 'serpentinite belt' (Korsch and Harrington, 1987; Aitchison et al., 1994; Och et al., 2003), is most prominent along a long (c. $150 \mathrm{~km}$ ), 


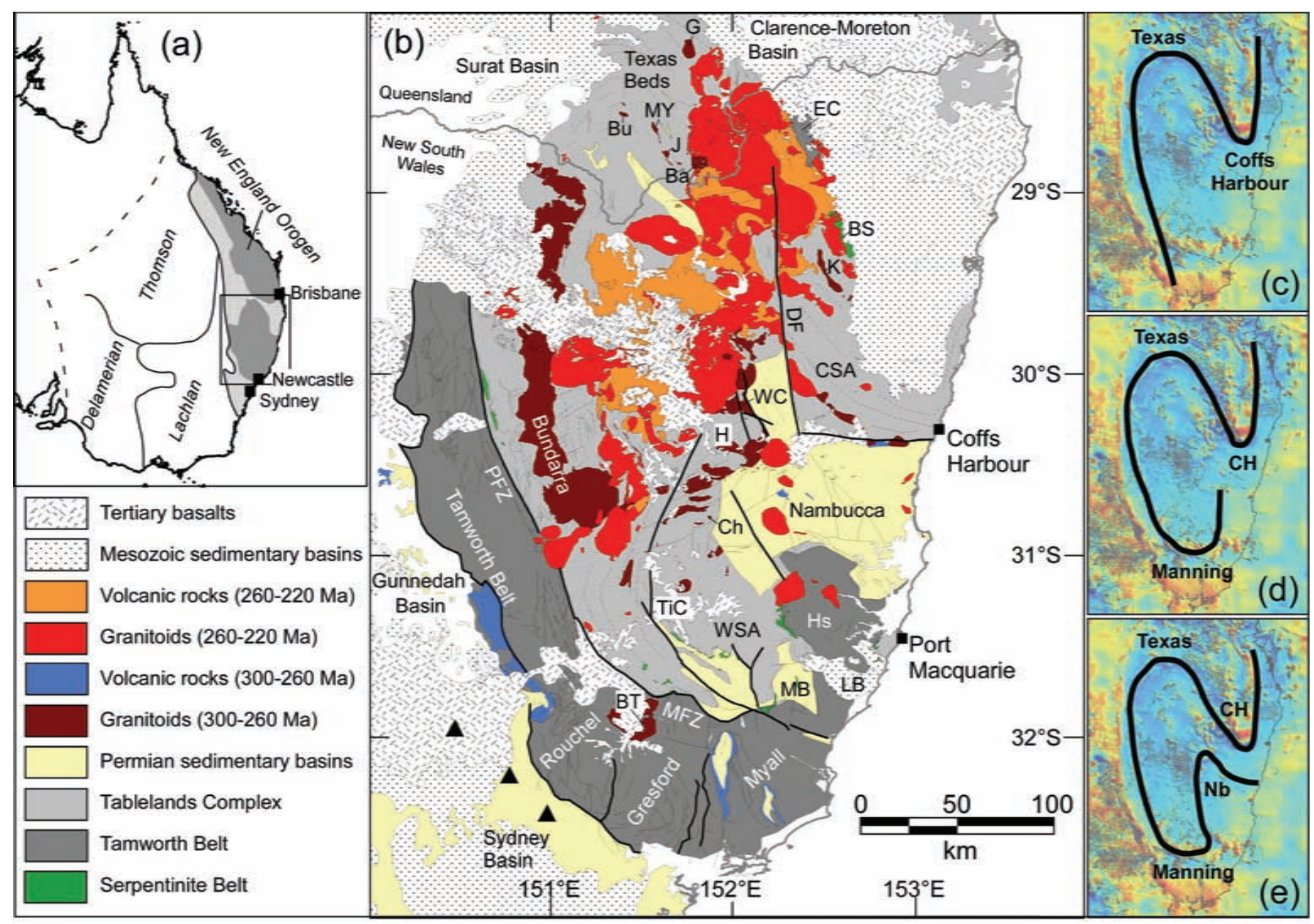

Figure 1 (a) Location map. Dashed line = possible location of the Tasman Line (after Glen, 2005). (b) Geological map of the southern New England Orogen. Triangles = an Early Carboniferous volcanic arc (under cover). Ba, Ballandean Granite; BS, Baryulgil Serpentinite; BT, Barrington Tops Granodiorite; Bu, Bullaganang Granite; Ch, Cheyenne Complex; CSA, Coffs Harbour Association; DF, Demon Fault; EC, Emu Creek Block; Hs, Hastings Block; J, Jibbinbar Granite; K, Kaloe Granodiorite; LB, Lorne Basin; MB, Manning Basin; MFZ, Manning Fault Zone; MY, Mt You You Granite; PFZ, Peel Fault Zone; TiC, Tia Complex; WC, Wongwibinda Complex; WSA, Woolomin and Sandon Associations. (c), (d), (e) Alternative interpretations of the Texas, Coffs Harbour (CH), Manning and Nambucca (Nb) Oroclines on a background of the magnetic intensity image.

narrow belt $\mathrm{E}$ of the Tamworth belt, but can also be recognised in numerous smaller outcrops in the southern part of the area, including the town of Port Macquarie (Figure 1b). The rocks are oceanic in nature, and are associated with a dismembered early Paleozoic ophiolite that records earlier (Lachlan orogeny?) subduction and accretion processes prior to its incorporation in the Devonian subduction complex (Aitchison et al., 1994; Fukui et al., 1995).

The coupled Tamworth Belt and Tablelands Complex represent a Devonian-Carboniferous W-dipping subduction zone, with a volcanic arc that existed farther W. Much of the volcanic arc is covered by younger sedimentary rocks of the Surat, Gunnedah and Sydney basins (see triangles in Figure 1b), but its existence can be inferred from facies relationships within detrital sedimentary rocks of the Tamworth Belt that show an eastward transport of arc-related detritus into the forearc basin, and a gradual change from intermediate to silicic magmatism during arc maturation in the Carboniferous (Crook, 1964; Leitch, 1974; Cawood, 1983; Morris, 1988).

Forearc basin rocks are represented in the Tamworth Belt and in a series of correlative blocks farther S (Rouchel, Gresford, Myall and Hastings; Figure 1b). The rocks are associated with sedimentation on a shelf that, in the Tamworth Belt, was gradually deepening from $\mathrm{W}$ to E (Crook, 1964; Roberts and Engel, 1987). The sedimentary facies in the Hastings Block has an opposite facing (i.e. deepening from $\mathrm{E}$ to $\mathrm{W}$ ), and has been interpreted to be a displaced terrane of the Tamworth Belt (Korsch, 1977). Farther N , in northern New South Wales, there is another block with a comparable Carboniferous stratigraphy, the Emu Creek Block (Figure 1b), which likely represents a forearc basin terrane (Cross et al., 1987).

The Devonian-Carboniferous accretionary wedge rocks (Tablelands Complex) have been subdivided into a number of associations based on their sedimentary facies (e.g., Coffs Harbour, Woolomin and Sandon associations; Figure 1b) (Korsch, 1977). Typical lithologies include deep marine volcaniclastic turbidites, cherts and argillites, mafic volcanic rocks, and olistostromal deposits containing slabs of limestone, basalt, andesite and siltstone (Leitch and Cawood, 1980; Cawood, 1982; Fergusson, 1984). Rocks were subjected to varying degrees of metamorphism ranging from prehnitepumpellyite/lower greenschist (e.g., Texas Beds and Coffs Harbour Association, Korsch, 1978) to amphibolite (Tia and Wongwibinda metamorphic complexes; Binns, 1966; Stephenson and Hensel, 1982; 


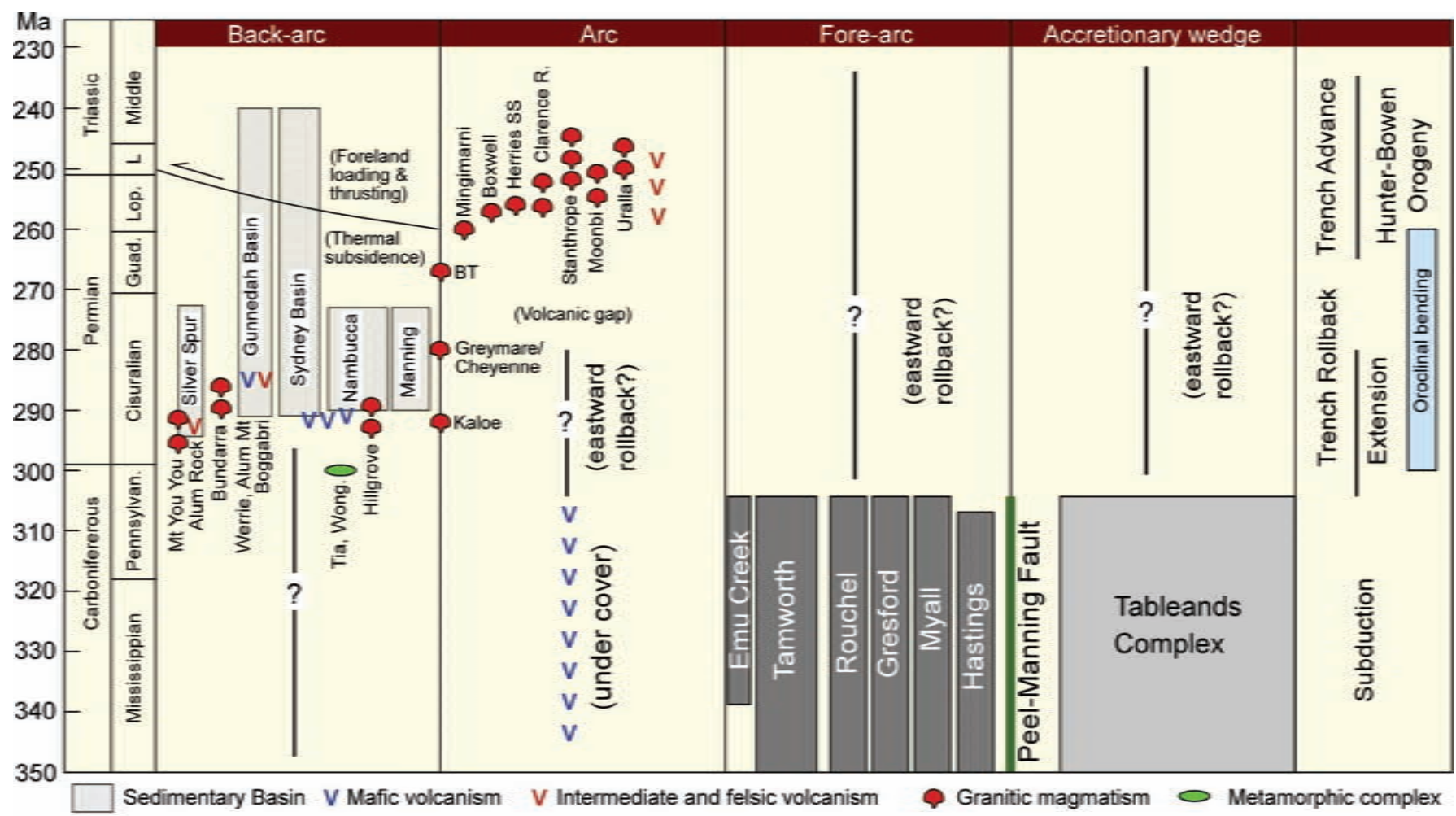

Figure 2 Temporal relations and tectonic setting of rock units in the southern NEO (partly modified after Cawood et al., 2011b). Guad., Guadalupian (“middle Permian”), Lop., Lopingian (late Permian). BT, Barrington Tops Granodiorite; Wong. Wongwibinda Complex.

Phillips et al., 2008; Danis et al., 2010; Craven et al., 2012) (Figure 1b). High-pressure rocks are relatively rare, but are recognised as an earlier blueschist assemblage in the Tia metamorphic complex (Phillips et al., 2008). Throughout the whole Tablelands Complex, rocks are commonly characterised by a penetrative structural fabric that most likely formed in the accretionary wedge prior to development of the oroclines (Fergusson, 1984; Murray et al., 1987).

\section{Early Permian rift basins and magmatism}

Two major associations of early Permian (Cisuralian) rocks are found in the southern NEO. The first group is associated with magmatic rocks, predominantly S-type granitoids, which intruded the Tablelands Complex throughout the whole southern NEO (Flood and Shaw, 1977; Shaw and Flood, 1981; Hensel et al., 1985; Phillips et al., 2011; Rosenbaum et al., 2012). The second group includes clastic sedimentary rocks and mafic volcanic rocks, which were deposited in rift basins during the early Permian (Leitch, 1988; Roberts et al., 2006; Korsch et al., 2009a).

The majority of S-type granitoids belong to the Bundarra and Hillgrove suites (Figures $1 \mathrm{~b}$ and $3 \mathrm{~b}$ ). The emplacement of these granitoids took place in a relatively short time interval, at 298-288 Ma, simultaneously with the intrusion of a number of other smaller S-type plutons in southern Queensland (Bullaganang, Mt You You, Jibbinbar and Ballandean granites) and the I-type Kaloe Granodiorite in northeastern NSW (Figure 1b) (Cawood et al., 2011a; Rosenbaum et al., 2012). The geochemistry of the Bundarra and Hillgrove suites was interpreted to indicate crustal melting in an extensional backarc setting (Jenkins et al., 2002). A backarc environment is accounted for by the fact that although these rocks are intruded into the Carboniferous accretionary wedge, by the early Permian, the subduction zone had retreated eastward bringing the accretionary wedge into a backarc position (Jenkins et al., 2002).

The intrusion of S-type granitoids during subduction rollback is also consistent with the development of coeval rift basins, which were developed throughout the whole New England Orogen in the early Permian and were accompanied by extensional deformation (Holcombe et al., 1997a; Korsch et al., 2009a). The early Permian sedimentary successions are well developed in the foreland area $\mathrm{W}$ of the NEO and are represented by the Sydney, Gunnedah and Bowen Basins (Totterdell et al., 2009). In the southern NEO, there are a number of structural blocks with a correlative early Permian stratigraphy (Leitch, 1988). The largest of which is the Nambucca Block, which appears in the "core" of the oroclinal structure E of the peripheral Sydney and Gunnedah basins (Figure 1b). Other early Permian sedimentary rocks are found in the Manning Block (also referred to as the Barnard Basin; Leitch, 1988) and in a number of smaller blocks in southern Queensland (Figure 1b).

Early Permian sedimentation was accompanied by bimodal magmatism (Asthana and Leitch, 1985; Jenkins et al., 2002), with volcanic material from the base of these sedimentary successions dated at 293-291 Ma (Roberts et al., 1996; Cawood et al., 2011a). These geochronological results indicate that sedimentation and volcanism in rift basins were contemporaneous with S-type magmatism, further supporting the idea that the early Permian rift basins developed in a hot backarc extensional environment, possibly linked to an eastward retreat of the subduction zone (Collins and Richards, 2008).

Following the pulse of widespread magmatism at 298-288 Ma, the southern NEO was subjected to a long period (20-25 Myr) with only scarce magmatism. S-type magmatism in the Bundarra Granite could have continued until c. $282 \mathrm{Ma}$ (Phillips et al., 2011), and there 
are two reported c. $280 \mathrm{Ma}$ ages from the small plutons of Greymare (Donchak et al., 2007) and Cheyenne Complex (Rosenbaum et al., 2012) (Figure 1b). The only known granitic magmatism in the 280 260 Ma time bracket is the I-type Barrington Tops Granodiorite (c. $267 \mathrm{Ma}$; Cawood et al., 2011a) located in the southernmost NEO (Figure 1b).

\section{Late Permian-Triassic magmatism}

Magmatism in the southern NEO recommenced in the late Permian (Lopingian) at c. $260 \mathrm{Ma}$ and involved voluminous magmatism associated with the emplacement of I-type granitoids and felsic volcanism (Shaw and Flood, 1981). This magmatic episode overlapped with a period of widespread E-W contractional deformation that affected the whole New England Orogen and is commonly referred as the Hunter-Bowen Orogeny (Collins, 1991; Holcombe et al., 1997b; Korsch et al., 2009b). Contractional deformation began 5-15 Myr prior to the onset of magmatism and continued until c. $230 \mathrm{Ma}$ (Holcombe et al., 1997b). During the Hunter-Bowen Orogeny, the Sydney and Gunnedah basins, that developed as backarc basins in the early Permian, were transformed into foreland basins (Collins, 1991; Korsch et al., 2009b).

Late Permian-Triassic granitoids have been subdivided by Shaw and Flood (1981) into three major suites: (1) metaluminous and K-poor, mainly tonalite and granodiorite of the Clarence River Supersuite; (2) K-rich quartz monzonites of the Moonbi Suite; and (3) less metaluminous quartz monzonites and granodiorite of the Uralla Suite. The majority of these plutons were emplaced at 260230 Ma (Shaw, 1994; Donchak et al., 2007), with the exception of the aforementioned I-type Barrington Tops (c. $267 \mathrm{Ma}$ ) and Kaloe (c. 292 Ma) Granodiorites (Cawood et al., 2011a). The geodynamic setting of the late Permian-Triassic magmatism is considered to be related to continental arc magmatism associated with the reestablishment of a W-dipping subduction zone (Bryant et al., 1997; Carr, 1998; Jenkins et al., 2002). A suite of younger (230-200 Ma) I-type granitoids are aligned N-S closer to the coast and are possibly post-orogenic (Figure 3c).

\section{Mesozoic sedimentary basins and Cenozoic basalts}

Early-Middle Triassic sedimentary rocks were deposited in the Sydney, Gunnedah and Lorne basins, and Late Triassic-Cretaceous sequences accumulated in the Surat and Clarence-Moreton basins (Figure $1 \mathrm{~b}$ and 2). The basal units of the latter basins unconformably overlie the rocks of the NEO and include a large volume of quartzrich sand grains derived from the uplifted granitic basement (Donchak et al., 2007). Cenozoic volcanism in the southern NEO is predominantly basaltic. An earlier stage of volcanism, which took place mainly in the Eocene-Oligocene, resulted in extensive lava fields (e.g., Sutherland and Fanning, 2001). A series of younger (25$16 \mathrm{Ma}$ ) central volcanoes are generally younging from $\mathrm{N}$ to $\mathrm{S}$ (Vasconcelos et al., 2008), and are possibly marking a hotspot track that was superimposed on the northward moving Australian plate during the past 35 Myrs (Knesel et al., 2008).

\section{The structure of the oroclines}

\section{Evidence from pre-Permian rocks}

The curved structure of the Texas and Coffs Harbour oroclines is evident from variations in the orientations of the dominant steeply
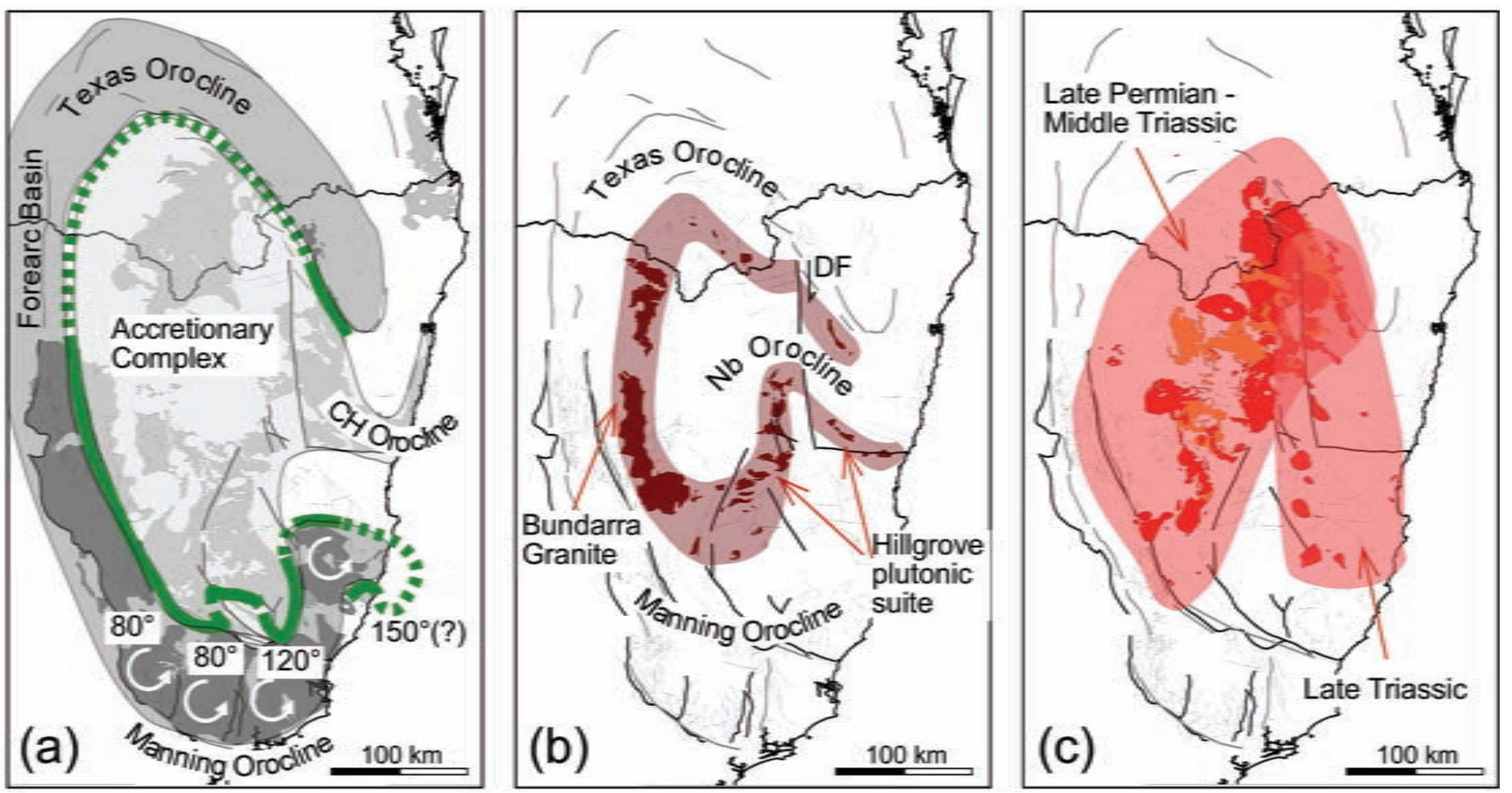

Figure 3 Spatial distribution of (a) pre-oroclinal elements of the Devonian to Carboniferous subduction complex; (b) early Permian (298288 Ma) pre- to syn-oroclinal magmatic belt (Rosenbaum et al., 2012); (c) post-oroclinal late Permian-Triassic magmatism. The background maps show lineaments inferred from aeromagnetic images and major faults. The inferred continuation of the contorted serpentinite belt is shown in the green line. Counterclockwise block rotations in (a) are after Geeve et al. (2002) and Klootwijk (2009). CH, Coffs Harbour; Nb, Nambucca. Dextral displacement along the Demon Fault (DF) in b) is after McPhie and Fergusson (1983). 
dipping structural fabric, which shows a map-scale curvature that delineates the oroclinal structure (Korsch, 1981; Lennox and Flood, 1997; Li et al., 2012). The structural fabric and fold plunges are steep or sub-vertical (Figure 4a), indicating that the curvatures recognised in a plan view are true bends around vertical axes.

The continuation of the Tamworth Belt around the Texas and Coffs Harbour oroclines is obscured by younger sedimentary rocks, but its existence under cover is supported by geophysical evidence (Wartenberg et al., 2003). Moreover, the appearance of the Emu Creek Block in the eastern limb of the Texas Orocline (Figure 1b) may represent the continuation of this belt (Figure 3a). Similarly, the position of the Baryulgil Serpentinite (Figure 1b) is consistent with the continuation of the serpentinite belt along the eastern limb of the Texas Orocline (Korsch and Harrington, 1987).

Farther S, the apparent arrangement of forearc basin terranes around the Manning Orocline, and the curvature of the Serpentinite Belt (Figure 3a), support the existence of this orocline (Korsch and Harrington, 1987). Constraints from paleomagnetic studies are limited and incomplete (Cawood et al., 2011b), but the available data are generally consistent with oroclinal bending, indicating counterclockwise rotations of the Rouchel $\left(80^{\circ}\right)$, Gresford $\left(80^{\circ}\right)$ and Myall $\left(120^{\circ}\right)$ Blocks during the latest Carboniferous or early Permian
(Geeve et al., 2002). Paleomagnetic data from the Hastings Block, however, was interpreted to indicate a clockwise rotation of $130^{\circ}$ around a vertical axis (Schmidt et al., 1994), which is not compatible with the expected rotations during oroclinal bending. The validity of this clockwise rotation, however, is debated (Klootwijk, 2009). An alternative interpretation that is consistent with oroclinal bending, is based on a comparison of the Namurian paleopoles from the Hastings Block and the northern Tamworth Belt, and is indicative of $150^{\circ}$ counterclockwise rotations of the former relative to the latter (Klootwijk, 2009).

Further support for oroclinal bending in the Manning Orocline has been presented by Cawood et al. (2011b), who tested the agreement of available paleomagnetic data with two alternative tectonic models. The result of this analysis indicated that the previously suggested tectonic models, accounting only for the development of the Texas and Coffs Harbour oroclines by dextral strike-skip faulting (e.g., Offler and Foster, 2008), are not permissible. In contrast, a model involving a northward translation of forearc basin terranes during oroclinal bending in the Manning Orocline is consistent with the paleomagnetic data (Cawood et al., 2011b).

Notwithstanding the supporting evidence for oroclinal bending in the Manning Orocline, its structure remains elusive and
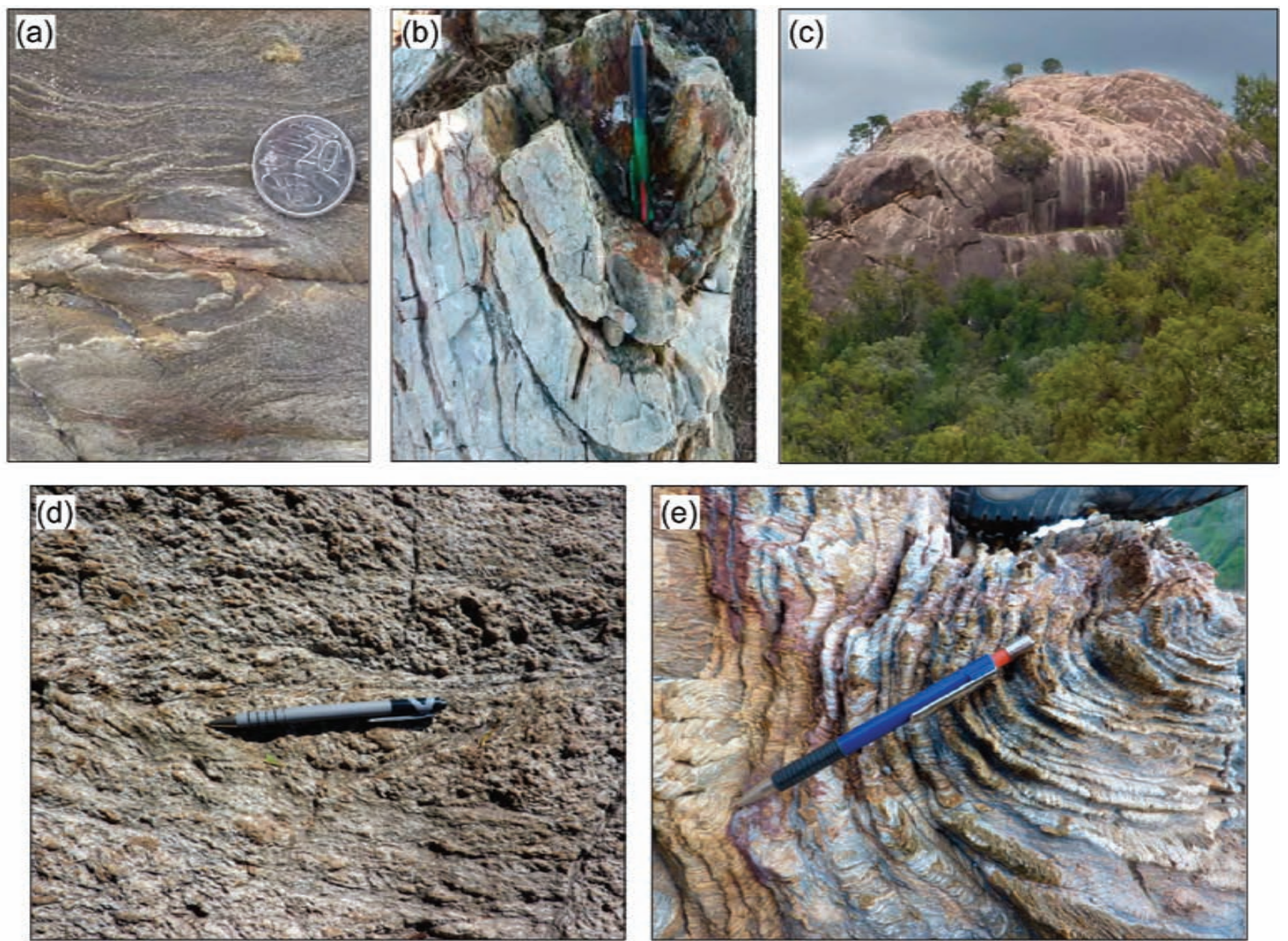

Figure 4 a) Pre-oroclinal steeply dipping structural fabric in the Texas Beds and associated isoclinal folds; b) An isoclinal, steeply plunging,

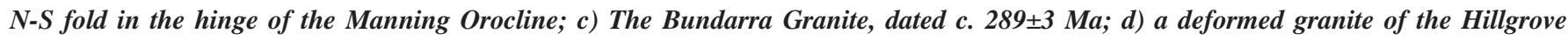
plutonic suite (Henry River Granite) dated 293 \pm 5 (Rosenbaum et al., 2012); e) Strong ductile fabric and overprinting relationships in the early Permian Nambucca Block. Crenulation cleavage $\left(S_{3}\right)$ with $S_{2}$ quartz-mica domains in the microlithons and a mesoscopic $\mathrm{F}_{4}$ fold. 
controversial. One of the major reasons for this controversy is that, unlike the Texas and Coffs Harbour oroclines, the orientations of bedding and dominant secondary foliations, are not curved around the orocline, but are predominantly oriented c. N-S, roughly parallel to tectonic contacts and the axial planes of regional and minor folds (Figure 4b) (Collins, 1991). One explanation for that is that preoroclinal structural features were transposed to $\mathrm{c}$. N-S orientation by late- or post-oroclinal deformation.

Deformation and metamorphism in the southernmost NEO is indeed much more intense in comparison to the relatively low strain deformation around the Texas and Coffs Harbour oroclines. In two localities within this area (Tia and Wongwibinda complexes, Figure 1 ), the originally accretionary wedge rocks were affected by multiphase ductile deformation and high-grade (amphibolite) metamorphism (Stephenson and Hensel, 1982; Dirks et al., 1992; Landenberger et al., 1995; Phillips et al., 2008; Danis et al., 2010; Craven et al., 2011). Whether this deformation and metamorphism predated oroclinal bending, or occurred simultaneously with the development of the Manning Orocline, is an open question. Subsequent deformation associated with the Hunter-Bowen orogeny was responsible for further folding and thrusting along N-S structures, accompanied by sinistral strike-slip faulting (Collins, 1991).

\section{Evidence from Permian rocks}

Recent U-Pb geochronology from early Permian rocks in the southern NEO has considerably improved our understanding of the oroclinal structure (Rosenbaum et al., 2012). In particular, the recognition that $S$-type granite emplacement occurred contemporaneously in the Bundarra and Hillgrove suites (Figure 4c, d), led Rosenbaum et al. (2012) to conclude that the lateral continuation of these plutons defines the hinge of the Manning Orocline (Figure 3b). Similarly, early Permian (298-288 Ma) granitoids are apparently curved around the Texas Orocline, and could possibly define a fourth bend (Nambucca Orocline; Figure 3b).

The remarkable curvature of the early Permian granitoids raises a major question with regards to the timing of oroclinal bending. If granite emplacement occurred at 298-288 Ma in a quasi-linear belt that was subsequently subjected to bending, then the timing of oroclinal bending must be younger than c. 288 Ma. However, paleomagnetic data seem to suggest that block rotations in the Manning Orocline took place prior to the Asselian (299-295 Ma) (Geeve et al., 2002). It is therefore possible that the curved shape of the early Permian Hillgrove and Bundarra Suites is at least partly a primary curvature rather than the result of oroclinal bending. In other words, S-type magmatism may have occurred in an arcuate fashion that mimicked the shape of the earlier curvature. The model proposed by Rosenbaum et al. (2012) considers a combination of a primary or progressive curvature, which was amplified and refolded by subsequent deformation. Evidence for such multi-phase deformation history is recorded in the superposition of strong ductile fabrics within the early Permian sedimentary rocks of the Nambucca Block (Figure 4e).

In contrast with the early Permian granitoids, which clearly mimic the shape of the oroclines, the spatial distribution of late PermianTriassic granitoids is distributed along a broad NE-SW field that crosscut the oroclinal structure (Figure 3c). This phase of magmatism is interpreted to postdate oroclinal bending, thus providing a minimum age constraint of c. $260 \mathrm{Ma}$ for their formation.

\section{Tectonic implications and concluding remarks}

The southern NEO seems to represent one of the most contorted orogens in the world, comprising of three or four tight bends (Figure 1c, d, e and Figure 3). The oroclinal structure is supported by structural analysis (Korsch, 1981; Lennox and Flood, 1997; Li et al., 2012), available paleomagnetic data (Cawood et al., 2011b) and geochronological results (Cawood et al., 2011a; Rosenbaum et al., 2012), but all these datasets are still incomplete and require further investigations. In particular, structural information from the hinge zones of the Manning and Nambucca oroclines is relatively scarce, with existing data indicating complex deformational history involving high-grade metamorphism and multiple generations of folding (Dirks et al., 1992; Danis et al., 2010). The link between the development of these metamorphic complexes (Tia and Wongwibinda complexes, Figure $1 \mathrm{~b}$ ) and the oroclinal structure is still unclear.

The formation of the oroclines occurred in the time bracket of 300-260 Ma, i.e., in the early-middle Permian (CisuralianGuadalupian; Figure 2). Based on paleomagnetic constraints (Geeve et al., 2002; Klootwijk, 2009), it seems that the formation of the Manning Orocline initiated relatively early (c. 300-295 Ma). The Texas Orocline also records an earlier stage $(>290 \mathrm{Ma})$ of oroclinal bending, which was followed by a second stage of deformation that took place after the deposition of early Permian sedimentary rocks in rift basins (Aubourg et al., 2004; Li et al., 2012).

Perhaps the most intriguing observation is the link between the first stage of oroclinal bending, the development of widespread extensional rift basins and the emplacement of S-type magmatism. This may suggest that during the early Permian, the whole southern NEO was in a backarc position relative to a retreating subduction zone. In such tectonic environments, orogenic curvature could be achieved by a combination of primary subduction curvatures and secondary oroclinal bending, triggered by variations along strike in rollback velocities and heterogeneous subduction (Rosenbaum and Mo, 2011). Whether this style of tectonic activity is applicable to the development of the southern NEO is a major question that should be addressed in future studies.

\section{Acknowledgements}

Research was funded by the Australian Research Council (DP0986762). The manuscript benefitted from the comments by Evan Leitch, Chris Fergusson and Peter Jell. I also wish to thank Pengfei Li for discussions and Perach Nuriel for assisting with the illustrations.

\section{References}

Aitchison, J.C., Blake, M.C.J., Flood, P.G. and Jayko, A.S., 1994, Paleozoic ophiolitic assemblages within the southern New England orogen of eastern Australia: Implications for growth of the Gondwana margin: Tectonics, v. 13 , pp. $1135-1149$.

Asthana, D. and Leitch, E.C., 1985, Petroi metabasalt: alkaline within-plate mafic rocks from the Nambucca slate belt, northeastern New South Wales: Australian Journal of Earth Sciences, v. 32, pp. 261-277.

Aubourg, C., Klootwijk, C. and Korsch, R.J., 2004, Magnetic fabric constraints on oroclinal bending of the Texas and Coffs Harbour blocks: New England Orogen, eastern Australia, in Martín-Hernández, F., Lüneburg, C.M., Aubourg, C. and Jackson, M. (eds), Magnetic Fabric: Methods and 
Applications: Geological Society of London, Special Publication, v. 238, pp. 421-445.

Binns, R.A., 1966, Granitic intrusions and regional metamorphic rocks of Permian age from the Wongwibinda District, north-eastern New South Wales: Royal Society of New South Wales, Journal and Proceedings, v. 99 , pp. 5-36.

Bryant, C.J., Arculus, R.J. and Chappell, B.W., 1997, Clarence River Supersuite: 250 Ma Cordilleran tonalitic I-type intrusions in eastern Australia: Journal of Petrology, v. 38, pp. 975-1001.

Carr, P.F., 1998, Subduction-related Late Permian shoshonites of the Sydney Basin, Australia: Mineralogy and Petrology, v. 63, pp. 49-71.

Cawood, P.A., 1982, Structural relations in the subduction complex of the Paleozoic New England fold belt, eastern Australia: Journal of Geology, v. 90 , pp. $381-392$.

Cawood, P.A., 1983, Modal composition and detrital clinopyroxene geochemistry of lithic sandstones from the New England Fold Belt (east Australia): a Paleozoic forearc terrane: Geological Society of America, Bulletin, v. 94, pp. 1199-1214.

Cawood, P.A. and Leitch, E.C., 1985, Accretion and dispersal tectonics of the Southern New England Fold Belt, Eastern Australia, in Howell, D.G. (ed), Tectonostratigraphic terranes of the Circum-Pacific region: CircumPacific Council for Energy and Mineral Resources, Earth Science Series, Houston, pp. 481-492.

Cawood, P.A., Leitch, E.C., Merle, R.E. and Nemchin, A., 2011a, Orogenesis without collision: Stabilizing the Terra Australis accretionary orogen, eastern Australia: Geological Society of America, Bulletin, v. 123, pp. 2240-2255.

Cawood, P.A., Pisarevsky, S.A. and Leitch, E., 2011b, Unravelling the New England Orocline, east Gondwana accretionary margin: Tectonics, v. 30, TC5002, doi:10.1029/2011TC002864.

Collins, W.J., 1991, A reassessment of the "Hunter-Bowen orogeny': tectonic implications for the southern New England fold belt: Australian Journal of Earth Sciences, v. 38, pp. 409-423.

Collins, W.J. and Richards, S.W., 2008, Geodynamic significance of S-type granites in circum-Pacific orogens: Geology, v. 36, pp. 559-562.

Craven, S.J., Daczko, N.R. and Halpin, J.A., 2011, Thermal gradient and timing of high-T-low-P metamorphism in the Wongwibinda Metamorphic Complex, southern New England Orogen, Australia. Journal of Metamorphic Geology, v. 30, pp. 3-20.

Crook, K.A.W., 1964, Depositional environmental and provenance of Devonian and Carboniferous sediments in the Tamworth Trough, N.S.W: Linnean Society of New South Wales, Journal and Proceedings, v. 97, pp. $41-53$.

Cross, K.C., Fergusson, C.L. and Flood, P.G., 1987, Contrasting structural styles in the Paleozoic subduction complex of the Southern New England Orogen, Eastern Australia, in Leitch, E. and Scheibner, E. (eds), Terrane Accretion and Orogenic Belts: American Geophysical Union, Geodynamics Series, v. 19, pp. 83-92.

Danis, C.R., Daczko, N.R., Lackie, M.A. and Craven, S.J., 2010, Retrograde metamorphism of the Wongwibinda Complex, New England Fold Belt and the implications of 2.5D subsurface geophysical structure for the metamorphic history: Australian Journal of Earth Sciences, v. 57, pp. 357-375.

Dirks, P.H.G.M., Hand, M., Collins, W.J. and Offler, R., 1992, Structuralmetamorphic evolution of the Tia complex, New England fold belt; thermal overprint of an accretion-subduction complex in a compressional back-arc setting: Journal of Structural Geology, v. 14, pp. 669-688.

Donchak, P.J.T., Bultitude, R.J., Purdy, D.J. and Denaro, T.J., 2007, Geology and mineralisation of the Texas Region, south-eastern Queensland: Queensland Geology, v. 11, pp. 1-96.

Fergusson, C.L., 1984, Tectono-stratigraphy of a Palaeozoic subduction complex in the central Coffs Harbour Block of north-eastern New South Wales: Australian Journal of Earth Sciences, v. 31, pp. 217-236.

Flood, R.H. and Shaw, S.E., 1977, Two "S-type" granite suites with low initial 87Sr/86Sr ratios from the New England Batholith, Australia: Contributions to Mineralogy and Petrology, v. 61, pp. 163-173.
Fukui, S., Watanabe, T., Ithaya, T. and Leitch, E.C., 1995, Middle Ordovician high PT metamorphic rocks in eastern Australia: Evidence from K-Ar ages: Tectonics, v. 14, pp. 1014-1020.

Geeve, R.J., Schmidt, P.W. and Roberts, J., 2002, Paleomagnetic results indicate pre-Permian counter-clockwise rotation of the southern Tamworth Belt, southern New England Orogen, Australia: Journal of Geophysical Research, v. 107, p. 2196, doi:2110.1029/2000JB000037.

Glen, R.A., 2005, The Tasmanides of eastern Australia, in Vaughan, A.P.M., Leat, P.T and Pankhurst, R.J. (eds), Terrane Processes at the Margins of Gondwana: Geological Society of London, Special Publication, v. 246, pp. $23-96$

Hensel, H.D., McCulloch, M.T. and Chappell, B.W., 1985, The New England Batholith: constraints on its derivation from $\mathrm{Nd}$ and $\mathrm{Sr}$ isotopic studies of granitoids and country rocks: Geochimica et Cosmochimica Acta, v. 49 , pp. $369-384$.

Holcombe, R.J., Stephens, C.J., Fielding, C.R., Gust, D., Little, T.A., Sliwa, R., McPhie, J. and Ewart, A., 1997a, Tectonic evolution of the northern New England Fold Belt: Carboniferous to Early Permian transition from active accretion to extension, in Ashley, P.M. and Flood, P.G. (eds), Tectonics and Metallogenesis of the New England Orogen: Geological Society of Australia, Special Publication, v. 19, pp. 66-79.

Holcombe, R.J., Stephens, C.J., Fielding, C.R., Gust, D., Little, T.A., Sliwa, R., McPhie, J. and Ewart, A., 1997b, Tectonic evolution of the northern New England Fold Belt: The Permian-Triassic Hunter-Bowen event, in Ashley, P.M. and Flood, P.G. (eds), Tectonics and Metallogenesis of the New England Orogen: Geological Society of Australia, Special Publication, v. 19, pp. 52-65.

Jenkins, R.B., Landenberger, B. and Collins, W.J., 2002, Late Palaeozoic retreating and advancing subduction boundary in the New England Fold Belt, New South Wales: Australian Journal of Earth Sciences, v. 49, pp. 467-489.

Klootwijk, C., 2009, Sedimentary basins of eastern Australia: Paleomagnetic constraints on geodynamic evolution in a global context: Australian Journal of Earth Sciences, v. 56, pp. 273-308.

Knesel, K.M., Cohen, B.E., Vasconcelos, P.M. and Thiede, D.S., 2008, Rapid change in drift of the Australian plate records collision with Ontong Java plateau: Nature, v. 454, pp. 754-757.

Korsch, R.J., 1977, A framework for the palaeozoic geology of the southern part of the New England Geosyncline: Geological Society of Australia, Journal, v. 25, pp. 339-355.

Korsch, R.J., 1978, Regional-scale thermal metamorphism overprinting lowgrade regional metamorphism, Coffs Harbour Block, northern New South Wales: Royal Society of New South Wales, Journal and Proceedings, v. 111, pp. 89-96.

Korsch, R.J., 1981, Deformational history of the Coffs Harbour Block: Royal Society of New South Wales, Journal and Proceedings, v. 114, 17-22.

Korsch, R.J. and Harrington, H.J., 1987, Oroclinal bending, fragmentation and deformation of terranes in the New England Orogen, eastern Australia: American Geophysical Union, Geodynamics Series, v. 19, pp. 129-139.

Korsch, R.J., Totterdell, J.M., Cathro, D.L. and Nicoll, M.G., 2009a, Early Permian East Australian Rift System: Australian Journal of Earth Sciences, v. 56, pp. $381-400$.

Korsch, R.J., Totterdell, J.M., Fomin, T. and Nicoll, M.G., 2009b, Contractional structures and deformational events in the Bowen, Gunnedah and Surat Basins, eastern Australia: Australian Journal of Earth Sciences, v. 56, pp. 477-499.

Landenberger, B., Farrell, T.R., Offler, R., Collins, W.J. and Whitford, D.J., 1995, Tectonic implications of Rb-Sr biotite ages for the Hillgrove Plutonic Suite, New England Fold Belt, N.S.W., Australia: Precambrian Research, v. 71, pp. 251-263.

Leitch, E.C., 1974, The geological development of the southern part of the New England Fold Belt: Geological Society of Australia, Journal, v. 21, pp. $133-156$.

Leitch, E., 1988, The Barnard Basin and the early Permian development of the southern part of the New England Fold Belt, in Kleeman, J.D. (ed.), New England Orogen - Tectonics and Metallogenesis: University of New 
England, Armidale, pp. 61-67.

Leitch, E.C. and Cawood, P.A., 1980, Olistoliths and debris flow deposits at ancient consuming plate margins: an eastern Australian example: Sedimentary Geology, v. 25, pp. 5-22.

Lennox, P.G. and Flood, P.G., 1997, Age and structural characterisation of the Texas megafold, southern New England Orogen, eastern Australia, in Ashley, P.M. and Flood, P.G. (eds), Tectonics and Metallogenesis of the New England Orogen: Geological Society of Australia, Special Publication, v. 19, pp. 161-177.

Li, P., Rosenbaum, G. and Donchak, P.J.T., 2012, Structural evolution of the Texas Orocline, eastern Australia: Gondwana Research, (in press).

McPhie, J. and Fergusson, C.L., 1983, Dextral movement on the Demon Fault, northeastern New South Wales: a reassessment (Australia): Royal Society of New South Wales, Journal and Proceedings, v. 116, pp. 123-127.

Morris, P.A., 1988, Volcanic arc reconstruction using discriminant function analysis of detrital clinopyroxene and amphibole from the New England fold belt, eastern Australia: Journal of Geology, v. 96, pp. 299-311.

Murray, C.G., Fergusson, C.L., Flood, P.G., Whitaker, W.G. and Korsch, R.J., 1987, Plate tectonic model for the Carboniferous evolution of the New England Fold Belt (Australia): Australian Journal of Earth Sciences, v. 34, pp. 213-236.

Och, D.J., Leitch, E.C., Caprarelli, G. and Watanabe, T., 2003, Blueschist and eclogite in tectonic melange, Port Macquarie, New South Wales, Australia: Mineralogical Magazine, v. 67, pp. 609-624.

Offler, R. and Foster, D.A., 2008, Timing and development of oroclines in the southern New England Orogen, New South Wales: Australian Journal of Earth Sciences, v. 55, pp. 331-340.

Phillips, G., Hand, M. and Offler, R., 2008, P-T-t deformation framework of an accretionary prism, southern New England Orogen, eastern Australia: Implications for blueschist exhumation and metamorphic switching: Tectonics, v. 27, pp.1-15.

Phillips, G., Landenberger, B. and Belousova, E.A., 2011, Building the New England Batholith, eastern Australia - Linking granite petrogenesis with geodynamic setting using Hf isotopes in zircon: Lithos, v. 122, pp. 112.

Roberts, J. and Engel, B.A., 1987, Depositional and tectonic history of the southern New England orogen: Australian Journal of Earth Sciences, v. 34 , pp. 1-20.

Roberts, J., Claoueì-Long, J.C. and Foster, C.B., 1996, SHRIMP zircon dating of the Permian System of eastern Australia: Australian Journal of Earth Sciences, v. 43, 401-421.

Roberts, J., Offler, R. and Fanning, M., 2006, Carboniferous to Lower Permian stratigraphy of the southern Tamworth Belt, southern New England Orogen, Australia: Boundary sequences of the Werrie and Rouchel blocks: Australian Journal of Earth Sciences v. 53, pp. 249-284.
Rosenbaum, G., 2010, Structure of the New England oroclines, in Buckman, S. and Blevin, P.L. (eds), New England Orogen 2010, Conference Proceedings: University of New England, Armidale, pp. 297-302.

Rosenbaum, G. and Mo, W., 2011, Tectonic and magmatic responses to the subduction of high bathymetric relief: Gondwana Research, v. 19, pp. 571-582.

Rosenbaum, G., Li, P. and Rubatto, D., 2012, The contorted New England Orogen (eastern Australia): new evidence from U-Pb geochronology of Early Permian granitoids: Tectonics, 31, TC1006, doi:1010.1029/ 2011TC002960.

Schmidt, P.W., Aubourg, C., Lennox, P.G. and Roberts, J., 1994, Palaeomagnetism and tectonic rotation of the Hastings Terrane, eastern Australia: Australian Journal of Earth Sciences, v. 41, pp. 547-560.

Shaw, S.E., 1994, Late Permian-Triassic radiometric dates of granitoids and associated volcanics from the southern New England belt, in Veevers, J. and Powell, C.M. (eds), Permian-Triassic Pangean basins and foldbelts along the Panthalassan margin of Gondwanaland: Geological Society of America, Memoir, v. 184, pp. 147-159.

Shaw, S.E. and Flood, R.H., 1981, The New England batholith, eastern Australia: geochemical variations in time and space: Journal of Geophysical Research, v. 86, pp. 10530-10544.

Stephenson, N.C.N. and Hensel, H.D., 1982, Amphibolites and related rocks from the Wongwibinda metamorphic complex, northern N.S.W., Australia: Lithos, v. 15 , pp. 59-75.

Sutherland, F.L. and Fanning, C.M., 2001, Gem-bearing basaltic volcanism, Barrington, New South Wales: Cenozoic evolution, based on basalt K$\mathrm{Ar}$ ages and zircon fission track and U-Pb isotope dating: Australian Journal of Earth Sciences, v. 48, pp. 221-237.

Totterdell, J.M., Moloney, J., Korsch, R.J. and Krassay, A.A., 2009, Sequence stratigraphy of the Bowen-Gunnedah and Surat Basins in New South Wales: Australian Journal of Earth Sciences, v. 56, pp. 433-459.

Vasconcelos, P.M., Knesel, K.M., Cohen, B.E. and Heim, J.A., 2008, Geochronology of the Australian Cenozoic: A history of tectonic and igneous activity, weathering, erosion, and sedimentation: Australian Journal of Earth Sciences, v. 55, pp. 865-914.

Wartenberg, W., Korsch, R.J. and Schäfer, A., 2003, The Tamworth Belt in Southern Queensland, Australia: thrust-characterized geometry concealed by Surat Basin sediments, in McCann, T. and Saintot, A. (eds), Tracing Tectonic Deformation Using the Sedimentary Record: Geological Society of London, Special Publication, pp. 185-203.

Weil, A.B. and Sussman, A.J., 2004, Classifying curved orogens based on timing relationships between structural development and vertical-axis rotations, in Sussman, A.J. and Weil, A.B. (eds), Orogenic curvature: Integrating paleomagnetic and structural analyses: Geological Society of America, Special Paper, v. 383, pp. 1-15.

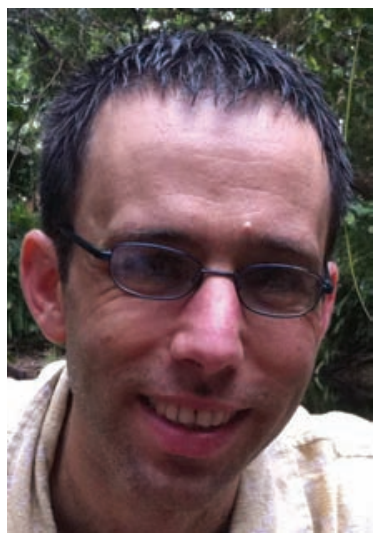

Gideon Rosenbaum is Associate Professor at the University of Queensland. He is teaching and conducting research in structural geology and tectonics, and is particularly interested in continental deformation and geodynamic reconstructions. He has been studying both modern and ancient tectonic environments using a combination of field-based approaches, kinematic modeling and numerical simulations. 